\title{
PENGARUH PEMBELAJARAN BERBASIS PEMECAHAN MASALAH BERBANTUAN JURNAL BELAJAR TERHADAP KEMAMPUAN METAKOGNITIF
}

\author{
Nurul Fathonah*, Suhadi Ibnu, Suharti \\ Program Studi Pendidikan Kimia Pascasarjana Universitas Negeri Malang \\ Jalan Semarang No.5 Malang 65146 \\ E-mail: pondokcapung@gmail.com
}

\begin{abstract}
Abstrak : Tujuan penelitian adalah untuk mengetahui perbedaan kemampuan metakognitif mahasiswa yang dibelajarkan dengan pemecahan masalah berbantuan jurnal belajar dengan tanpa bantuan jurnal belajar. Penelitian ini termasuk dalam eksperimen semu dengan menggunakan rancangan the matching only-Postest only control group design. Penelitian ini melibatkan dua kelas yaitu offering I sebagai kelas eksperimen dan offering G sebagai kelas kontrol. Kelas kontrol dibelajarkan dengan model pemecahan masalah dan kelas ekperimen dibelajarkan dengan model pemecahan masalah disertai penulisan jurnal jurnal belajar. Data pada penelitian ini adalah skor jurnal belajar dan lembar inventori metakognitif. Hasil penelitian menunjukkan bahwa kemampuan metakognitif mahasiswa yang dibelajarkan dengan model pemecahan masalah disertai jurnal belajar lebih tinggi daripada mahasiswa yang dibelajarkan dengan model pemecahan masalah tanpa disertai jurnal belajar.
\end{abstract}

Kata kunci : pemecahan masalah, jurnal belajar,metakognitif.

\begin{abstract}
The aim of this research is to find out whether the metacognitive ability of students involved in problem-solving based learning combined with learning journal is higher than that of the student in problemsolving without learning journal. This study employed a quasi-experimental by using the matching only-Postest only control group design. The population involved 2 (two) classes: offering I as an experiment group, and offering $\mathrm{G}$ as the control group. The control group was taught by problem-solving model, and the experiment group was taught by problem-solving augmented with learning journal. The measurements are learning journal scores and metacognitive awareness. The result shows metacognitive ability of students involved in problemsolving method combined with learning journal is higher than that of students involved in problem-solving without learning journal.
\end{abstract}

Keyword: problem solving, learning journal, metacognitive

\section{PENDAHULUAN}

Kimia dasar merupakan mata kuliah di perguruan tinggi khususnya yang memiliki jurusan kimia ataupun pendidikan kimia. Salah tujuan mahasiswa mempelajari kimia dasar adalah agar pada akhir pendidikan mahasiswa memahami dasar ilmu kimia, prinsip-prinsip dan cara penentuan kimia, prinsip dan cara analisis kualitatif dan kuantitatif, serta terampil menggunakan peralatan laboratorium kimia. Agar dapat mencapai tujuan tersebut mahasiswa hendaknya dilatih untuk dapat mengembangkan kesadaran akan berpikirnya sendiri. Salah satu alternatif yang dapat dilakukan untuk dapat mengembangkan kesadaran akan proses perpikir sendiri adalah dengan mengembangkan pengetahuan dan keterampilan metakognisi. Metakognisi sangat berperan dalam penyelesaian masalah kimia dasar. Kemampuan metakognisi yang dimiliki mahasiswa dapat meningkatkan kapasitas belajar yang penuh makna dan membentuk serta mempengaruhi untuk mengkonstruksi pemahaman [1]. Metakognisi mahasiswa memilki peranan penting dalam menyelesaikan masalah, khususnya dalam mengatur mengontrol aktivitas kognitif mahasiswa. Pengembangan kemampuan metakognisi dalam perkuliahan merupakan suatu upaya yang sangat penting dilakukan. Hal ini sesuai dengan salah satu tujuan dari pendidikan tinggi, yaitu mentransformasikan dan mengembangkan kemampuan mahasiswa, termasuk untuk merancang apa yang akan dilakukan, melaksanakan apa yang sudah direncanakan, memonitor dan mengevaluasi apa yang sedang dan sudah dilakukan, sehingga mereka menjadi kritis, kreatif, inovatif, mandiri, percaya diri, dan bertanggung jawab (Peraturan Pemerintah nomor 17 tahun 2010 tentang pengelolahan dan penyelenggaraan pendidikan).

Untuk itulah diperlukan suatu inovasi proses pembelajaran yang mampu untuk meningkatkan dan melatih metakognisi mahasiswa. Metakognisi dapat dibangun ketika mahasiswa melaksanakan pemecahan masalah. Selama proses pemecahan masalah, kesadaran kognisi mahasiswa dapat ditumbuhkan karena memberikan arahan agar mahasiswa bertanya pada dirinya apakah 
memahami apa yang sedang dipelajari atau dipikirkan. Mahasiswa dipandu untuk dapat menyadari apa yang diketahui dan apa yang tidak diketahui serta bagaimana pemecahan masalahnya, membuat perencanaan pendekatan pemecahan masalah, membuat tahap-tahap pemecahannya, memberi alasan mengapa melakukan demikian, memonitor proses pemecahan masalah dan kemajuan ke arah tujuan saat melaksanakan rencana, dan mengevaluasi apa yang sudah dilakukan. Hal ini sesuai dengan pernyataan bahwa metakognisi dapat dikembangkan dalam suatu lingkungan pembelajaran pemecahan masalah [2].

Metode pemecahan masalah memiliki empat tahapan utama yang harus dilakukan, yaitu (1) pemahaman terhadap masalah/analisis masalah, (2) pemikiran suatu rencana penyelesaian, (3) pelaksanaan rencana pemecahan/implementasi, (4) peninjauan kembali hasil pemecahan masalah/verifikasi [3]. Zoller [4] menyatakan bahwa pengajaran dengan metode pemecahan masalah merupakan pengajaran yang dimulai dengan pertanyaan-pertanyaan yang mengarah pada konsep, prinsip dan hukum kemudian dilanjutkan dengan kegiatan pemecahan masalah disebut pemecahan masalah. Penelitian Simanjuntak [5] yang mengungkapkan bahwa pembelajaran berbasis pemecahan masalah pada mata kuliah fisika dasar dapat meningkatkan metakognisi dan pemahaman konsep mahasiswa.

Pada implementasinya proses berpikir sangat berperan dalam keberhasilan dalam memecahkan suatu masalah. Setiap mahasiswa memiliki kesadaran berpikir dan daya ingat yang berbedabeda. Hal ini akan berpengaruh dalam proses pemecahan masalah yang dilakukan. Indriyana $\mathrm{dkk}$ [6] mengungkapkan ditemukan fakta bahwa mahasiswa banyak mengalami kesulitan dalam proses penyelesaian masalah. Kesulitan dalam pemecahan masalah dapat terjadi dimungkinkan karena mahasiswa belum terlatih untuk memanfaatkan informasi yang ada, serta belum terampil mengatur strategi dalam menyelesaikan tugas. Kesadaran akan proses berpikir bermanfaat agar mahasiswa dapat mengarahkan pembelajarannya untuk merencanakan pendekatan dalam penyelesaian tugas, memonitor aktivitas selama proses pemecahan dan mengecek hasil pembelajaran [7]. Proses berpikir juga erat kaitannya dengan kemampuan penyelesaian masalah, mengambil keputusan, menentukan teknik belajar yang sesuai untuk dirinya [8]. Salah satu cara yang dapat dipergunakan untuk melatih proses berpikir adalah dengan menggunakan catatan yang tersusun dalam jurnal belajar dalam kegiatan pembelajaran [9].

Jurnal belajar berasal dari istilah learning Journal yang merupakan dokumen yang secara terus menerus bertambah dan berkembang. Biasanya ditulis oleh mahasiswa sebagai rekaman terhadap perkembangan materi dan pemahaman yang sedang dipelajari [10]. Jurnal belajar (learning journal) sering juga disebut jurnal reflektif yaitu sebuah dokumen yang secara terus menerus bertambah dan berkembang, biasanya oleh seorang pembelajar untuk mencatat setiap kemajuan belajar [11]. Tujuan penulisan jurnal belajar adalah meningkatkan hasil belajar melalui proses menulis dan berfikir tentang proses belajar [12].

Penulisan jurnal dapat meningkatkan kemampuan metakognitif mahasiswa [13]. Strategi metakognitif pada diri mahasiswa dapat dilakukan dalam 3 tahapan proses, yaitu perencanaan diri (self palnning), pemontitoran diri (self monitoring) dan evaluasi diri (Self Evaluating). Pada penelitian ini penulisan jurnal belajar dilakukan pada saat sebelum pembelajaran berlangsung merencanakan pembelajaran yang akan dilakukan, kemudian pada saat pembelajaran berlangsung untuk mengontrol/memantau perkembangan belajarnya, dan terakhir sesudah pelajaran selesai untuk mengevaluasi ketercapaian tujuan pembelajaran yang dilakukan. Dengan kebiasaan menulis jurnal belajar seperti diharapkan kesadaran metakognitif mahasiswa meningkat. Hal ini sejalan dengan Penelitian yang dilakukan oleh Atfiyah [14] menunjukan bahwa penggunaan jurnal belajar pada pembelajaran berbasis inkuiri terbimbing tidak hanya meningkatkan hasil belajar namun kemampuan metakognitif mahasiswa dalam pokok bahasan sifat koligatif, penelitian ini didukung oleh penelitian Sabilu [15] yang melaporkan bahwa penerapan jurnal belajar dalam pembelajaran multistrategi mampu meningkatkan kesadaran metakognitif.

Berdasarkan definisi pemecahan masalah dan jurnal belajar diatas, keduanya bisa dipadukan, karena pembelajaran pemecahan masalah diawali dengan proses bertanya tentang bagaimana dan apa yang harus dilakukan untuk menyelesaikan suatu masalah, apa yang diperlukan untuk menjawab pertanyaan-pertanyaan, dan bagaimana menyelesaikan atau menjawab masalah . Sedangkan jurnal belajar berfungsi untuk proses berpikir mahasiswa dalam mengidentifikasi konsep-konsep yang dibutuhkan dalam menyelesaikan masalah, serta menghubungkan konsep-konsep yang baru diperoleh selama kegiatan pemecahan masalah berlangsung dengan pengetahuan awal. Denagn demikian mahasiswa terbiasa merencanakan pembelajaran sendiri diharapkan kemampuan metakognitifnya akan semakin meningkat.

\section{METODE PENELITIAN}

Penelitian dilaksanakan di jurusan kimia salah satu perguruan tinggi negeri di kota Malang pada mahasiswa semester 1. Penelitian ini termasuk dalam eksperimen semu dan menggunakan 
rancangan the matching only-posttesst only control group design [16]. Pada rancangan ini masingmasing group memiliki kesempatan untuk menjadi kelas kontrol maupun eksperimen. Kelas kontrol dibelajarkan dengan model pemecahan masala $h$ dan kelas ekperimen dibelajarkan dengan model pemecahan masalah disertai jurnal belajar. Pengambilan sampel dilakukan dengan teknik cluster random sampling. Berdasarkan teknik pengambilan sampel tersebut diperoleh dua kelas, yaitu off $G$ dan off I. Secara skematis rancangan penelitian yang digunakan dalam penelitian ini disajikan pada Tabel 1.

Tabel 1. Pola Desain Penelitian

\begin{tabular}{ccc}
\hline Subjek & Perlakuan & Pasca \\
\hline $\mathrm{E}$ & $\mathrm{X}$ & $\mathrm{O}$ \\
$\mathrm{K}$ & $\mathrm{C}$ & $\mathrm{O}$ \\
\hline
\end{tabular}

Keterangan :

E: Kelas Eksperimen

K: Kelas Kontrol

$\mathrm{X}:$ Pembelajaran berbasis pemecahanan masalah disertai jurnal belajar

$\mathrm{C}$ :Pembelajaran berbasis pemecahanan masalah.

$\mathrm{O}$ : Tes kemampuan metakognitif

Instrumen yang digunakan dalam penelitian ini dikelompokkan menjadi dua, yaitu

Skor maksimum kesadaran metakognitif a dalah 208 dengan kriteria perkembangan sangat bai k. Berdasarkan Tabel 4.5 diketahui bahwa pada ma hasiswa kelas eksperimen rata-rata skor kemampua n metakognitif 142,32 yang artinya memiliki kema mpuan metakognitif yang sudah berkembang baik. Sedangkan pada mahasiswa kelas kontrol diperoleh rata-rata skor kemampuan metakognitif 132.28 yan $\mathrm{g}$ artinya mahasiswa memiliki kemampuan metako gnitif yang sudah berkembang baik. Berdasarkan sk or rata-rata dapat dilihat bahwa kedua kelas memili ki rata-rata kemampuan metakognitif yang sudah b erkembang baik, tetapi skor rata-rata pada kelas eks perimen lebih tinggi dibandingkan kelas kontrol. K emampuan metakognitif yang sudah berkembang b aik menunjukkan mahasiswa sadar dengan cara ber instrumen perlakuan dan instrumen pengukuran. Instrumen perlakuan yang meliputi rencana pelaksanaan pembelajaran (RPP) dan Lembar Kegiatan Mahasiswa (LKM). Instrumen pengukuran yaitu lembar inventori kemampuan metakognitif mahasiswa metakognitif awareness inventory (MAI) [17] dan telah dikembangkan oleh Latiful Atfiyah dan Rahmawati [18] dengan validasi oleh ahli sebesar $92,70 \%$ dan reabilitas sebesar 0,72 dalam bentuk skala Likert yang terdiri dari 52 butir pernyataan. Lembar inventori kemampuan metakognitif diberikan setelah tiga kali pertemuan pertama sebelum sampel diputarData yang diperoleh dari penelitian dianalisis secara statistik dan dideskripsikan. Analisis statistik yang digunakan adalah analisis independent sample $\mathrm{T}$ test.

\section{HASIL PENELITIAN DAN PEMBAHASAN}

A. Hasil Penelitian

Kemampuan metakognitif mahasiswa diukur dengan mengunakan inventori kemampuan metakognitif yang disusun mengadaptasi Metacognitive Awarness Inventory (MAI) yang dikembangkan oleh Schraw and Denisson. Ringkasan kemampuan metakognitif mahasiswa dapat dilihat dalam Tabel 2 berikut.

pikirnya dan dapat membedakan tahap elaborasi in put dan output dan proses berpikirnya.

Pengujian hipotesis dilakukan dengan menggunakan independent sample $T$ test dengan menggunakan program SPSS 17 for windows. Pengambilan keputusan dilakukan dengan membandingkan nilai signifikasi dengan alfa. Jika nilai signifikasi $<5 \%$, maka $\mathrm{H}_{0}$ ditolak dan $\mathrm{H}_{1}$ diterima, sebaliknya jika nilai signifikasi, 5\%, maka $\mathrm{H}_{0}$ diterima dan $\mathrm{H}_{1}$ ditolak. Ringkasan hasil analisis pengaruh model pembelajaran yaitu integrasi jurnal belajar pada pembelajaran berbasis pemecahan masalah dan dengan tanpa integrasi jurnal terhadap kemampuan metakognitif diberikan pada Tabel 3.

Tabel 2. Ringkasan Skor Kemampuan Metakognitif Mahasiswa

\begin{tabular}{|c|c|c|c|c|}
\hline Kelas & $\mathrm{N}$ & Standar deviasi & $\begin{array}{l}\text { Rata-rata Skor } \\
\text { Kemampuan Metakognitif }\end{array}$ & Kriteria \\
\hline Eksperimen & 31 & 16.71 & 142.32 & Berkembang baik \\
\hline Kontrol & 35 & 10.98 & 132.28 & Berkembang baik \\
\hline
\end{tabular}

Tabel. 3. Ringkasan hasil uji independent sample T test

\begin{tabular}{ccccc}
\hline \multirow{2}{*}{$\begin{array}{c}\text { Dependent } \\
\text { Variable }\end{array}$} & \multicolumn{2}{c}{$\begin{array}{c}\text { Leven'test For Equalty of } \\
\text { Variance }\end{array}$} & \multicolumn{2}{c}{ t-test for Equality of means } \\
\cline { 2 - 5 } & $\mathrm{F}$ & $\mathrm{Sig}$ & $\mathrm{t}$ & $\mathrm{Sig}$ (2-tailed) \\
\hline $\begin{array}{l}\text { Kemampuan } \\
\text { Metakognitif }\end{array}$ & 3.981 & 0.050 & 2.914 & 0.005 \\
\hline
\end{tabular}


Berdasarkan Tabel 3 tentang hasil analisis dengan uji independent sample $\mathrm{T}$ test menunjukkan bahwa mahasiswa kelas kontrol yang dibelajarkan dengan model pemecahan masalah, dan mahasiswa kelas e ksperimen yang dibelajarkan dengan pemecahan $\mathrm{m}$ asalah disertai jurnal belajar berbeda signifikan, di mana nilai signifikansi kemampuan metakognitif (0 $.005)<(0,05)$, Hal ini berarti Ho ditolak dan H1 dit erima, yaitu ada perbedaan kemampuan metakognit if yang signifikan antara mahasiswa yang dibelajar kan dengan model pemecahan masalah, dengan ma hasiswa yang dibelajarkan dengan pemecahan masa lah disertai jurnal belajar. Hal ini didukung dengan perbedaan rata-rata hasil kemampuan metakognitif mahasiswa yang dibelajarkan dengan perlakuan ter sebut.

\section{B. Pembahasan}

Perbedaan kemampuan metakognitif
mahasiswa disebabkan adanya kebiasaan
mahasiswa dalam menulis jurnal belajar pada saat
sebelum, selama, dan setelah pembelajaran akan
menjadikan mahasiswa mampu
merencanakan/menyiapkan pembelajaran yang
akan dilakukan, memonitor/mengontrol kemajuan
belajaranya serta mengevaluasi hasil belajar yang
telah dicapai.

Pada kelas ekperimen, secara umum untuk pertemuan ke-1-3 indikator pembelajaran yang diberikan sama halnya dengan kelas kontrol. Proses pembelajaran diawali dengan dengan penjelasan tujuan dan sistem pembelajaran hari ini. Selanjutnya dosen membagikan LKM dan lembar jurnal belajar kepada tiap mahasiswa. Sebelum masuk pada kegiatan inti, mahasiswa diminta untuk menuliskan jurnal tahap 1 yaitu self planning. Penulisan jurnal tahap 1 bertujuan untuk merencanakan pembelajaran hari ini. Pada tahap ini, mahasiswa diminta untuk menuliskan apa yang akan dipelajari, kemudian prior knowledge yang dibutuhkan untuk mempelajari materi hari ini. Setelah mereka menuliskan, kemudian beberapa mahasiswa secara acak diminta dosen untuk menyampaikan pekerjaannya, kemudian ditanggapi oleh dosen dan teman-teman yang lain. Setelah penulisan jurnal tahap 1, barulah masuk pada kegiatan inti dimana mahasiswa memecahkan problem pada LKM dengan langkah problem solving yaitu tahap analisis masalah, tahap perencanaan, tahap pemecahan masalah, dan tahap pengecekan. Setelah memecahkan beberapa problem dosen meminta mahasiswa mengerjakan jurnal belajar tahap 2 yaitu self monitoring. Penulisan jurnal tahap 2 ini bertujuan untuk memonitor konsep-konsep dan keterampilan apa saja yang telah dikuasi dan yang belum dikuasai. Kemudian diakhir pembelajaran mahasiswa juga diminta menulis jurnal belajar tahap 3 yaitu self evaluating, dimana pada jurnal tahap 3 ini, selain diminta menuliskan konsep dan keterampilan yang telah diperoleh, selain itu mahasiswa juga diminta menyimpulkan pembelajaran hari ini.

Identifikasi proses berpikir mahasiswa didasarkan pada tulisan yang dituangkan dalam jurnal belajar mahasiswa. Dari delapan kali tatap muka dengan kompetensi yang berbeda, maka proses berpikir mahasiswa berdasarkan jurnal belajarnya nampak pada Tabel 4 berikut ini.

Tabel 4. Skor rata-rata jurnal belajar.

\begin{tabular}{|c|c|c|c|c|c|}
\hline \multirow[t]{2}{*}{ TM } & \multicolumn{3}{|c|}{ Skor rata-rata aspek } & \multirow{2}{*}{$\begin{array}{l}\text { Skor } \\
\text { total }\end{array}$} & \multirow[t]{2}{*}{ Kriteria } \\
\hline & A & B & $\mathrm{C}$ & & \\
\hline 1 & 0.85 & 1,25 & 2,48 & 4,58 & sedang \\
\hline 2 & 1 & 1,56 & 2,75 & 5,31 & Sedang \\
\hline 3 & 1 & 2,48 & 3,48 & 7,23 & Baik \\
\hline \multicolumn{6}{|c|}{ Keterangan: } \\
\hline TM & \multicolumn{3}{|c|}{ : Tatap Muka } & & \\
\hline A & \multicolumn{3}{|c|}{ : Aspek Self Planning } & & \\
\hline B & \multicolumn{3}{|c|}{ : Aspek Self Monitoring } & & \\
\hline $\mathrm{C}$ & \multicolumn{3}{|c|}{ : Aspek Self Evaluating } & & \\
\hline
\end{tabular}

Berdasarkan Tabel 4, secara umum pada pertemuan ke-1 mahasiswa masih terlihat kebingungan baik dalam menuliskan jurnal belajar maupun proses pemecahan masalah. Berdasarkan hasil jurnal belajar menunjukkan bahwa mahasiswa masih belum mampu berpikir secara sistematis dengan kriteria rata-rata sedang. Mahasiswa dengan hasil proses berpikir tidak sistematis ditunjukkan dengan belum mampunya dalam menyampaikan apa yang dirasakan saat pembelajaran dengan detail. Misalnya salah satu mahasiswa berikut ini menuliskan jurnal tentang konsep dan keterampilan yang diperoleh seperti berikut ini:

'Konsep yang sudah diperoleh yaitu massa atom relatif, massa molekul relatif.'

Pernyataan yang disampaikan tersebut menunjukkan mahasiswa belum mampu mendeskripsikan dengan detail, apa itu konsep massa atom relatif dan massa molekul. Mahasiswa belum bisa memetakan konsep-konsep apa saja yang sudah diperoleh, kaitan antar konsep dan konsep-konsep yang belum dikuasi. Akibatnya untuk menyelesaikan masalah yang belum jelas mahasiswa mengalami kesulitan untuk mencari solusi atau pemecahan masalah. Hal ini terlihat dari terhambatnya pada proses pengerjaan LKM dengan tahap problem solving dengan skor rata-rata LKM 168.

Kondisi kecenderungan kesulitan mendeskripsikan apa yang dirasakan juga muncul pada refleksi yang menanyakan kesimpulan pembelajaran hari ini. Lebih dari 70\% mahasiswa masih menyatakan seperti berikut ini: 
Perkuliahan yang saya rasakan senang dan nyaman. Serta materi yang disampaikan mudah dipahami.'

Pernyataan yang disampaikan tersebut menunjukkan mahasiswa belum mampu mendeskripsikan dengan detail, apa yang dirasakan 'senang' dan 'nyaman'. Selain itu mahasiswa tersebut juga tidak menyampaikan materi apakah yang dimaksudkan mudah dipahami tersebut.

Pertemuan 2 hingga ke-3 menunjukkan hasil adanya proses berpikir mahasiswa yang cenderung lebih sistematis. Nampaknya hasil refleksi yang dilakukan dosen dengan memberikan masukan pada setiap akhir perkuliahan memberikan dampak nyata. Pada refleksi tatap muka 2 , direncanakan untuk lebih menekankan penulisan jurnal belajar dengan memandu secara jelas pada setiap komponen melalui pembatasan waktu penulisan. Adanya pemberian penekanan, pemanduan, dan memberikan waktu untuk menuliskan jurnal belajar menjadikan mahasiswa lebih fokus dalam menulis sehingga berdampak pada proses berpikir yang lebih sistematis meskipun secara perlahan dan butuh penyesuaian.

Dengan demikian secara sistematis mahasiswa sudah dapat mengkaitkan antara kesulitan yang dihadapi dan solusi pemecahan yang akan dilaksanakan. Selain itu, nampaknya pembiasaan penulisan jurnal belajar menjadikan mahasiswa mulai memikirkan bagian penting yang perlu dipahami termasuk apa yang sudah dipahaminya. Kondisi hasil penelitian dengan menggunakan jurnal belajar yang menunjukkan lebih sistematisnya proses berpikir mahasiswa. Hal ini berdampak pada proses problem solving yang dilakukan, dimana mahasiswa pada pertemuan ke-2 dan ke-3 mahasiswa sudah beradaptasi dengan cepat dalam melakukan problem solving dalam memecahkan problem-problem LKM, dilihat dari skor rata-rata LKM 2 dan 3 berturut-turut 74 dan 80, mengalami kenaikan signifikan

Jurnal belajar merupakan salah satu alternatif untuk melakukan refleksi yang dapat dilakukan oleh mahasiswa [19]. Mahasiswa dapat menuliskan segala sesuatu yang telah dialaminya yang terkait dengan kegiatan pembelajaran dalam jurnal belajar yang dibuatnya, sehingga dengan demikian mahasiswa dapat lebih termotivasi dan dapat memahami dirinya sendiri, dalam kegiatan pembelajarannya.

Menurut Countinho [20] kemampuan metakognitif merupakan kemampuan yang merujuk kepada aktivitas untuk mengontrol berpikir dan proses belajar seseorang seperti perencanaan, memonitor/mengontrol pemahaman, dan mengevaluasi hasil belajar. Dengan kemampuan mahasiswa untuk bisa merencanakan, mengontrol kemajuan belajar dan mengevaluasi hasil belajarnya akan menjadikan pembelajaran yang dilakukan oleh mahasiswa menjadi lebih terarah dan efektif. Menurut Nurhadi [21] dengan jurnal belajar mahasiswa dapat mengetahui kelemahan dan kelebihan dirinya yang merupakan suatu modal dasar untuk belajar.

Kajian tentang penelitian terdahulu seperti penelitian dari Dianovsky dan Wink [22] menyatakan bahwa proses pembelajaran kimia dengan menggunakan jurnal belajar mempunyai kolerasi yang positif dan signifikan terhadap kemampuan metakognitif mahasiswa. Penggunaan jurnal belajar dalam pembelajaran multistrategi dapat meningkatkan kemampuan metakognitif mahasiswa dlaam belajar biologi. Senada dengan hasil tersebut, Blakey dan Spence [23] menyatakan bahwa pengembangan kemampuan metakognitif bisa dilakukan melalui penulisan jurnal belajar. Penelitian lain diungkapkan oleh Liu dan Shen [24] bahwa penulisan jurnal belajar akan meningkatkan kemampuan metakognitif mahasiswa. Thorpe [25] juga mengungkapkan bahwa jurnal belajar bermanfaat bagi mahasiswa dalam membantu pengembangan kemampuan refleksi dan instropeksi diri. Refleksi dan introspeksi diri ini terjadi ketika mahasiswa menulis jurnal karena dalam menulis jurnal ini sswa mencatat dan mengilutrasikan semua pengalamannya yang dapat membantu mahasiswa mensintesiskan dan menterjemahkkan pikiran dan prilaku dalam bentuk tulisan dan tabel dan grafik, dapat membandingkan pengetahuan awal dengan pengetahuan yang baru diterima, memilih strategi berpikir yang tepat, serta dapat mengetahui kelemahan dan kelebihan atas tindakan yang diambil.

Kemampuan metakognitif yang lebih tinggi akan berdampak pada prestasi belajar yang tinggi pula. Hasil ini terlihat dari skor yang didapat oleh mahasiswa pada pokok bahasan stoikiometri dari mahasiswa yang dibelajarkan dengan jurnal belajar akan mempunyai prestasi yang lebih tinggi dibandingkan mahasiswa yang dibelajarkan dengan tanpa jurnal belajar. Sesuai dengan yang diungkapkan oleh Coutinho (2008) [26], bahwa mahasiswa mempunyai kemampuan metakognisi yang baik akan memiliki kemampuan akademik yang lebih baik dibandingkan dengan mahasiswa yang memiliki kemampuan metakognitif kurang baik.

\section{KESIMPULAN}

Berdasarkan hasil dan pembahasan dapat disimpulkan bahwa pembelajaran berbasis pemecahan masalah berbantuan jurnal belajar dapat meningkatkan kemampuan metakognitif mahasiswa. Hasil penelitian menunjukkan bahwa kemampuan metakognitif mahasiswa yang dibelajarkan dengan model pemecahan masalah disertai jurnal belajar lebih tinggi daripada mahasiswa yang dibelajarkan dengan model pemecahan masalah tanpa disertai jurnal belajar. 


\section{DAFTAR PUSTAKA}

[1] Anderson, D., \& Nashon, S. 2006. Predators of Knowledge Construction: Interpreting Students' Metacognition in an Amusement Park Physics Program. Wiley InterScience.

[2] Garrett, A.J., \& Mazzocco, M.M.M. 2006. Development of the Metacognitive Skills of Prediction and Evaluation in Children With or Without Math Disability. Learning Disabilities Research \& Practice, 21(2):77-87.

[3] Polya, G. 2004. How To Solve It (John Conway, Ed). United State of America: Princention University Press.

[4] Zoller, U., Lubezky, A., Nakhleh, M.B., \& Tessier, B. 1995. Success on Alghoritmic and LOCS Vs Conceptual Chemistry Exam Question. Journal Chemical Education, 72 (11).

[5] Simanjuntak, P.M. 2012. Pengembangan Model Pembelajaran Fisika Berbasis Pemecahan Masalah Untuk Meningkatkan Pengetahuan dan Keterampilan Metakognisi Mahasiswa. Jurnal INPAFI 1(1).

[6] Indrayana, T.P., Santyasa, W.I., \& Artawan, P. 2015. Pengaruh Model Problem Solving dan Scaffolding Terhadap Pemahaman Konsep Fisika Siswa Kelas XI IPA. Prosiding Pertemuan Ilmiah XXIX HFI Jateng \& DIY. Yogyakarta 25 April 2015.

[7] Darling. L. tanpa tahun. Thinking About Thingking: Metacognition. Stanford: University Scholl of Education.

[8] Arslan, S. 2012. The Influence of Environment Education on Critical Thinking and Environmental Attitude. Procedia-Social and Behavioral Sciences (55): 902-909.

[9] Cengiz, C., Karatas, O.F. 2015. Examining The Effects of Reflective Journals on Pre-service Science Teachers'General Chemistry Laboratory Achievement. Australian Journal of Teacher Education 40(10)

[10] Septiyana, K., Budi Prasetyo, A. P., \& Christij anti, W. (2013). Jurnal belajar sebagai strategi berpikir metakognitif pada pembelajaran siste $\mathrm{m}$ imunitas. Unnes Journal of Biology Educati on, 2(1).

[11] Anggraeni, S. (2009). Pengaruh Penggunaan J urnal Belajar (Learning Journal) Terhadap Ha sil Belajar Siswa pada Konsep Sistem Reprod uksi Manusia. Skripsi). Bandung: FMIPA Uni versitas Pendidikan Indonesia.

[12] Shen, C. Yi., \& Liu, H. C. 2011. Metacognitive Skills Development; A WebBased Approach in Higher Education. The Turkish Online Journal of Education Technolgy 10(2).

[13] Atfiyah, Latiful. 2013. Pengaruh Penggunaan Jurnal Belajar dalam Pembelajaran Inkuiri Terbimbing terhadap Hasil Belajar dan Kemampuan Metakognitif Siswa Pada Materi Sifat Koligatif. Tesis. Malang: PPs UM.

[14] Sabilu. M. 2009. Pengaruh Penggunaan Jurnal Belajar dalam Pembelajaran Multistrategi terhadap Kemampuan Kognitif dan Metakognitif Siswa SMA Negeri 9 Malang. Tesis. Malang: PPs UM.

[19] Fraenkel, J.R., \& Wallen, N. E. 2008. How to Design and Evaluate Reasearch in Eduaction $7^{\text {th }}$ Edition. New York: McGraw-Hill.

[20] Schraw, G., \& Denniso, R.S. 1994. Assessing Metacognitive Awareness. Contemporaty Educational Psychology, 19, 472-474,

[21] Trianto. 2008. Mendesain Pembelajaran Kontekstual (Contextual Teaching and Learning) di Kelas. Jakarta : Cerdas Pustaka Publisher.

[22] Coutinho, S.2007. The Relationship Between Goals, Metacognition, And Academic Sucsess. Educate Journal 7(1).

[23] Coutinho, S. 2008. Self-Efficacy, Metacognition, and Performance. North American Journal Of Psichology, 10(1).

[26] Thorpe, K. 2004. Reflective Learning Journals: from Concept to Practice. Reflective Practice, 5 (3): 327-343. 